\title{
Educational Television in El Salvador and Modernisation Theory*
}

\author{
HÉCTOR LINDO-FUENTES
}

Abstract. This article investigates the introduction of educational television in $\mathrm{El}$ Salvador in the late I96os, an Alliance for Progress project, in light of the preoccupations of the Cold War, the application of modernisation theory, the growing influence of a development community grounded in the social sciences and the Salvadorean elite's particular obsession with communism. The top-down approach used by the military regime to introduce a flurry of changes in the education system was facilitated by the extensive resources provided by international aid agencies and the US government. However, the reforms alienated Salvadorean teachers and fuelled teachers' strikes that are still remembered as pivotal moments in the urban mass movements of the I970s which preceded the civil war of the I980s.

Keywords: El Salvador, Alliance for Progress, modernisation theory, UNESCO, educational television, foreign aid, Wilbur Schramm

If educational reform succeeds [in El Salvador], then all else that we are trying to do will succeed.

If it does not succeed, and succeed swiftly, then no amount of good will or economic investment will be sufficient.

Lyndon B. Johnson, I $968^{1}$

\section{Introduction}

President Lyndon B. Johnson expressed his keen interest in the potential of television as a tool for economic development during a stopover in American Samoa in October i 966. The island had implemented a novel

Héctor Lindo-Fuentes is Professor of Latin American History at Fordham University. Email: lindo@fordham.edu.

* This article has greatly benefited from numerous conversations with Erik Ching, with whom I am writing a more ambitious project related to this topic, from insightful comments and suggestions from my Fordham University colleague, Michael Latham, and from the comments made on earlier versions by the Journal's peer reviewers. I also acknowledge with gratitude the help of Alfredo Ramírez in El Salvador and of the personnel at the UNESCO Archive in Paris, the Walsh Library at Fordham University, and the Biblioteca del Museo Nacional at San Salvador.

${ }^{1}$ Lyndon B. Johnson, 'Remarks at the Alberto Masferrer Normal School, San Andres, El Salvador', 7 July i 968, in John Woolley and Gerhard Peters (eds.), The American Presidency Project (Santa Barbara), available at www.presidency.ucsb.edu/ws/?pid= 28994 . 
programme that used television to improve the school system. At his arrival at the Pago Pago airport, Johnson remarked that Samoa had 'become a showplace for progress', and that 'the pilot program of education which you have started may point the way to learning breakthroughs throughout the Pacific islands and Southeast Asia. Samoan children are learning twice as fast as they once did'. ${ }^{2}$ A month after returning from Pago Pago, Johnson appointed a task force to 'assess the value of educational television broadcasting for primary and secondary schools in less-developed countries'.

In April i 967 Johnson attended a summit with the Latin American heads of state in Punta del Este, Uruguay, to discuss how to 'work toward modernisation of Latin life'. 4 The meeting was meant to be a reaffirmation of US commitment to John F. Kennedy's massive foreign aid programme for Latin America, the Alliance for Progress. The White House Task Force on Educational Television in Less-Developed Countries had told the president in March that the Uruguay Conference would be an ideal opportunity to promote educational television and recommended a pilot project in El Salvador. ${ }^{5}$ In Punta del Este Johnson had a private meeting with the president-elect of El Salvador, Colonel Fidel Sánchez Hernández, to discuss 'the potentialities of instructional television for speeding educational development'. The project had enough priority to be mentioned explicitly in Johnson's formal remarks to the open session of the heads of state. He promised US technical and monetary support for the creation of 'an inter-American training center for educational broadcasting', and to set up 'a pilot educational television demonstration project in a Central American country that will teach the children by day and entertain and inform their families at night'. ${ }^{6}$

During the summer of the following year Johnson travelled to El Salvador for a meeting with the five Central American presidents. During the trip he visited a teachers' school where he announced US support for the

${ }^{2}$ Lyndon B. Johnson, 'Remarks Upon Arrival at Tafuna International Airport, Pago Pago, American Samoa', i 8 Oct. I 966, in Woolley and Peters (eds.), The American Presidency Project, available at www.presidency.ucsb.edu/ws/?pid $=27945$.

${ }^{3}$ Lyndon B. Johnson, 'Memorandum on Appointing a Task Force to Study the Role of Educational Television in the Less-Developed Countries', 26 Nov. I966, in Woolley and Peters (eds.), The American Presidency Project, available at www.presidency.ucsb.edu/ws/ index.php?pid $=\mathbf{2} 8048$.

${ }^{4}$ Lyndon B. Johnson, White House Diary, i4 April 1967, p. 4a, Lyndon B. Johnson Library and Museum, Austin, available at www.lbjlib.utexas.edu/johnson/archives.hom/Diary/ 1967/670414-05.asp.

${ }^{5}$ Leonard H. Marks, 'White House Task Force on Educational Television in LessDeveloped Countries: Summary and Recommendations', USAID Development Information Center, 27 June 1967, p. 3.

${ }^{6}$ Lyndon B. Johnson, 'Remarks in Punta del Este at the Public Session of the Meeting of American Chiefs of State', I3 April 1967, in Woolley and Peters (eds.), The American Presidency Project, available at www.presidency.ucsb.edu/ws/index.php?pid $=\mathbf{2 8 2 0 \mathrm { I }}$. 
introduction of instructional television with a loan of US\$ I,900,000 and the donation of US $\$ 700,000 .{ }^{7}$ In his official remarks Johnson mentioned that he had been 'greatly inspired' by the educational television experience in American Samoa, and was delighted that the Samoan accomplishments were 'going to be done and improved' in El Salvador. ${ }^{8}$ Since the television initiative in El Salvador was a pilot project, the United States Agency for International Development (USAID), the agency responsible for overseeing the initiative, planned to follow its progress with rigorous social science investigations. To design and carry out the research, USAID hired a team from the Institute for Communications Research at Stanford University, headed by Wilbur Schramm, a world authority on communications. Not coincidentally, Schramm had been the main author of the reports that persuaded President Johnson that the American Samoa experience with educational television was a success. President Johnson was well aware of Schramm's work; in 1964 he had even written a foreword for one of Schramm's books. ${ }^{\mathbf{9}}$

Educational television became one component of a comprehensive and controversial education reform started by the Sánchez Hernández administration in El Salvador after it came to power in 1967. The documents on the Salvadorean pilot project produced by Wilbur Schramm and the Stanford team shed light not only on the educational television component, but also on the broader whole of the reform. The reform consisted of I I main components designed to overhaul El Salvador's educational system.

I. Reorganisation of the Ministry of Education;

2. Extensive teacher training;

3. Curriculum revision;

4. Development of new teachers' guides and student workbooks;

5. Improvement of the system of school supervision to provide 'advice' instead of inspection;

6. Development of a wider diversity of technical training programmes in grades $\mathrm{X}-\mathrm{XII}$;

7. Extensive building of new schoolrooms;

8. Elimination of tuition in grades VII, VIII and IX;

9. Use of double sessions and reduced hours to teach more pupils;

ı. A new student evaluation system incorporating changes in promotion and grading policies; and

I I. Installation of a national instructional television system for grades VII-IX.10

7 Johnson, 'Remarks at the Alberto Masferrer Normal School'.

8 Ibid.

9 Daniel Lerner and Wilbur Schramm (eds.), Communication and Change in Developing Countries (Honolulu, 1967). Johnson's foreword is dated December i964.

10 John K. Mayo, Robert C. Hornik and Emile G. McAnany, 'Instructional Television in El Salvador's Educational Reform', Prospects: Quarterly Review of Education, vol. 5, no. I (1975), p. I 20. 
Even though it appears last in the list, Televisión Educativa (TVE) was the centrepiece of the reform. Not only did it receive the bulk of the reform's financial, human and political resources, but it was also seen as the core that provided the logic for all other elements of the reform. TVE began broadcasting in February 1969, first on commercial stations and later on the Ministry of Education's own channels. When the Stanford team asked a sample of Salvadorean parents in 1970 which of the new education policies they were aware of, almost all of them mentioned only educational television. Roughly 30 of the 40 international consultants on the reform worked directly with the television initiative. ${ }^{11}$ A study of the costs of instructional television carried out in 1972 showed that it accounted for half of the total reform budget between i 966 and $1970 .{ }^{12}$

The Salvadorean government dedicated an unprecedented amount of resources to education. During the main years of the reform the share of education expenditure in the national budget jumped from 22 per cent in I 967 to almost 37 per cent in 1972 , the highest share ever recorded in the country's history. ${ }^{13}$ The main source of funding for the reform came from international donors, including US\$ I m million in grants and loans from the United States, US\$ 5 million from the World Bank, and another US\$ 2 million from bilateral aid. ${ }^{14}$ The educational television project rapidly became a key component of the Alliance for Progress in El Salvador.

In the early years of the Alliance the country had received US support for school construction, housing, health centres, textbooks, food distribution, agricultural extension and rural resettlement, and loans for commercial agriculture, industry, roads, electricity and telephones. Although the list shows a good number of social projects, the bulk of the aid (about 80 per cent) was destined to provide credit for commercial agriculture, industry and roads. The loans strengthened an economic elite that navigated easily between long-established activities such as coffee exports, sugar production and banking, and more recent opportunities in beef and cotton exports and industry.

11 Ibid., p. I 22.

12 Academy for Educational Development (AED), 'Educational Reform and Instructional Television in El Salvador: Costs, Benefits and Payoffs. A Summary of Richard E. Speagle's Report', Information Center on Instructional Technology, Information Bulletin no. 2 (Washington DC, Oct. I972), p. 3.

13 Wilbur Schramm, 'Television and Educational Reform in El Salvador. Complete Report on the Second Year of Research', Stanford University, Institute for Communications Research, paper i97I-05 (I97I), pp. II-I2; Laurence Wolff, Educational Reform and Instructional Television in El Salvador: A Summary of Research Findings (Washington DC, 1973), p. Io.

14 These and all subsequent figures mentioned in the article are in current US dollars. 
It is worth noting that despite the rhetorical flourishes of the Salvadorean and US authorities, during the years of the Alliance El Salvador was not among the top recipients of US aid. Measured in per capita terms, economic assistance to El Salvador (loans and grants) was, on average, in the I 2 th position when compared to the rest of the countries of Latin America. The country's rank fluctuated between the 7 th and 17 th positions between 1962 and 1976 . For the same period El Salvador was in 13 th place in Latin America in per capita military aid. In the first five years of the Alliance the country received only US\$ 80 million in economic assistance, and US\$ 5 million in military aid. In this context the US\$ I I million devoted to the TVE project was a considerable figure, and the level of support for an individual social project was a significant departure from the record that the Alliance had established in El Salvador. ${ }^{15}$

The story of the introduction of educational television and its effects on El Salvador cannot be limited to a simple tale of one more foreign aid effort to support a school system. It is a far more complex story that includes the preoccupations of the Cold War, the emergence of an international development community grounded in the social sciences, and the Salvadorean elite's particular obsession with communism. The interaction of these factors had consequences that helped to create a mass movement in opposition to the regime.

The first section of this article will summarise the narrative constructed by the reports produced by the research team of the Stanford Institute for Communications Research. This summary is designed to show how the promoters of the project understood its goals and achievements from a narrow perspective that left out crucial elements of the local context. The second section will show how this apparently technical, apolitical narrative conformed to an approach to the use of mass media to promote development that was inspired by modernisation theory and formed part of the Cold War foreign policy of the United States. ${ }^{16}$ As the third section explains, the project was readily embraced by the Salvadorean authorities because they already had a similar project in mind and, more importantly, because the rationale that inspired the United States to pour millions of dollars into the project reinforced local understandings of modernity that legitimised the military regime that governed El Salvador. The final section interprets the failure of the reform in terms of the socio-political context of the ig6os and

${ }^{15}$ For US foreign aid figures, the best source is USAID, U.S. Overseas Loans and Grants (The Green Book), which can be found online at http://gbk.eads.usaidallnet.gov. For a list of projects during the first five years of the Alliance in El Salvador, see 'La Alianza cumple 5 años de progreso en El Salvador', El Diario de Hoy, i7 Aug. 1966.

16 Needless to say, this section owes a debt to James Ferguson, The Anti-Politics Machine: 'Development', Depoliticization, and Bureaucratic Power in Lesotho (Minneapolis, 1994). 
early I970s in El Salvador, and examines the role that the theoretical framework played in narrowing the field of vision of policymakers and reinforcing the authoritarian nature of the Salvadorean state. In the final analysis, this case helps to illustrate how the military regime, enabled by international donors, contributed to 'construct', to use Jeff Goodwin's expression, the revolutionary movement that challenged it. ${ }^{17}$

\section{The Narrative Produced by the Stanford Team}

The reports produced by the Stanford team between 1970 and 1976 presented a compelling narrative that justified, after the fact, the need for a radical change in the educational system in El Salvador, and presented educational television as the ideal technological fix for the problems of the school system. Since teachers were scarce and poorly trained, 'teleclasses' would be able to bring to schools excellent lectures that the local teacher, despite poor training, could supplement with follow-up questions and exercises.

The impact of TVE was not limited to the classroom. According to the reports, TVE became the catalyst for a profound systemic change in El Salvador's educational system. All the other elements of the reform - the specialised high schools, the curricular changes, the new centralised teachers' school, the new textbooks, even the organisation of the Ministry of Education - were designed to respond to the needs of the new system and to guarantee its success. In the words of one report:

The present educational reform in El Salvador was first conceived as little more than the placing of a television receiver in each classroom. As plans developed, however, and as the full implications of the introduction of new technology became clear, it was seen that television was not only an innovation important in its own right, but also a catalyst of change that would affect every aspect of education in El Salvador. ${ }^{18}$

As one of the Stanford reports noted, 'A major technological change has forced its own logic upon those who had decided to use it'. The same report went on to explain the Stanford team's view of the process:

El Salvador's educational leaders seem to have understood and accepted the implications that this innovation has for structural changes that go far beyond the placement of a piece of hardware in a classroom ... To our knowledge no other country has accepted so completely the implications that educational technology carries with it. We are in the process of studying an important test case to see

17 Jeff Goodwin, No Other Way Out: States and Revolutionary Movements, 1945-199I (Cambridge, 200I), p. 40.

18 Wilbur Schramm et al., 'Television and Educational Reform in El Salvador: Summary Report of the First Year of Research', AED Project Report Series, no. Io (Washington DC, I970), p. 3. 
whether television's role as a catalyst for systemic change as well as instructional medium for the classroom will achieve positive results. ${ }^{19}$

Three years after the introduction of TVE, most students in the seventh, eighth and ninth grades in public schools (equivalent to middle school in the US system), and many in private schools, received their mathematics, science, Spanish, English and social studies classes from a TV monitor. The 'teleteacher' taught for 20 minutes, and the classroom teacher then followed up by clarifying points and fielding questions. Classroom teachers were thought of as part of a 'team' with the teleteacher, and they had to be retrained to adapt to the new classroom dynamic. They received specialised training at a new teachers' college, where curricula were revised. ${ }^{20}$ The textbooks and teacher manuals written to teach the new curricula were tailored to accompany the televised lessons. The Ministry of Education was restructured to include a powerful administrative unit in charge of the new system. The daily classroom experience was transformed all over El Salvador. When they sat in front of the television screens, teachers and students received regular centrally transmitted messages.

Students were separated in experimental and control groups and given a battery of tests to measure their learning. The research 'suggested' that the quality of education was superior to the system it was replacing. Furthermore, the Stanford reports stated that there was a 'high probability' that the cost of educating each student was equal to, if not less than, what it was under the previous system. ${ }^{21}$ The introduction of TVE had faced teacher resistance, two strikes, and bureaucratic obstacles, but the reports explained how the system had succeeded, thanks to the strong leadership provided by the modernising minister of education, Walter Béneke.

It was planned that 500,000 students from first to ninth grade would eventually receive instruction from their teleteachers. In 1976 the international researchers had completed their study and Stanford University Press published a book containing their findings. They concluded that, thanks to TVE, the educational system in El Salvador reached more students, improved the quality of instruction, and standardised lessons. Supporters of the use of television in the classroom claimed that in addition to the promise of eventually saving costs, the new technology had been implemented with deference to

19 Robert C. Hornik et al., 'Television and Educational Reform in El Salvador: Summary Report of the First Year of Research (02/01/69-1 I/o I/69)', Stanford University, Institute for Communications Research, paper i $970-05$ (1970), p. 7.

20 Schramm et al., 'Television and Educational Reform: Summary Report of the First Year', p. 4; John K. Mayo and Robert C. Hornik, 'Television and Educational Reform in El Salvador: Report on the Fourth Year of Research', Stanford University, Institute for Communications Research, paper 1973-05 (1973), p. 5.

21 John K. Mayo, Robert C. Hornik and Emile G. McAnany, Educational Reform with Television: The El Salvador Experience (Stanford, I976). 
the needs of locals and with the support of the most sophisticated social science research methods. They claimed that the main problems with the system had to do with students' increased education and career expectations. Wilbur Schramm put the question succinctly: 'Would such aspirations be fulfilled by the opening up of new schools and job opportunities or would they be frustrated through a continuing lack of opportunity in these areas? ${ }^{\mathbf{2 2}}$

The Stanford narrative of the Salvadorean experience, pulled together from reports produced over four years, was backed at every point by survey data, statistical correlations, R-squared statistics and T-tests. Notwithstanding the technical language, the series of documents conformed to a narrative that echoed, element by element, a chapter on the American Samoa experience published in ${ }_{19} 67$ by a team led by none other than Schramm. ${ }^{23}$ Just like the Salvadorean reports, the paper on American Samoa told the story of a system that employed 'teachers with little training' where the introduction of educational television led to 'a complete reconstruction of a school system'. The experience in the classroom consisted of a 'teleclass' "which varies from eight to twenty-five minutes in length ... [with] the remainder of the period devoted to following up the telecast with explanations, review, drill, and other classroom activities'. Classroom teachers and their television counterparts were a 'teaching team'. The tentative conclusion was that the system was 'proving itself an effective stimulant to educational change and it does seem to be contributing to raising educational standards'. Although there was some teacher resistance, change was possible thanks to the 'vigour and determination of the governor' (in his writings on El Salvador, Schramm compared Salvadorean education minister Béneke to American Samoa governor Rex Lee). ${ }^{24}$ The system was not yet quite economically viable, but it would be if the number of students reached was high enough.

How is it possible that a system would evolve in exactly the same way in two distant places with completely different cultures, histories, geography, economy and demographics? To understand this problem one has to understand how these educational projects were conceived as experiments in the use of mass communications for development.

The narrative of the enormous promise of the use of television in education was not limited to the stories of American Samoa and El Salvador. In

22 Schramm, 'Television and Educational Reform in El Salvador: Complete Report on the Second Year', p. 5 .

${ }^{23}$ Schramm et al., 'Educational Television in American Samoa', in UNESCO, International Institute for Educational Planning, New Educational Media in Action: Case Studies for Planners: $I$ (Paris, I967).

24 Wilbur Schramm, 'Instructional Television in the Educational Reform of El Salvador', AED, Information Center on Instructional Technology, Information Bulletin no. 3 (Washington DC, I973), p. 75. 
the I96os the use of national television systems to educate the public was a topic of discussion in many countries, but there was a qualitative difference between how they were used in the industrialised world and in poor countries like El Salvador. In the United States, for example, there was a campaign to create non-commercial channels for educational and cultural purposes. After a rich public discussion, the public television network that emerged was a system sensitive to local and regional diversity and aimed to promote the arts and education. ${ }^{25}$ After a government decision, the Salvadorean TVE began as a completely centralised system designed to broadcast uniform lessons to every classroom. The result of the broad discussion in the United States was a lasting system that managed to combine the advantages of central coordination and adaptation to regional needs. ${ }^{\mathbf{2}}$ The result of the government project in El Salvador was a rigid system that was abandoned within a decade. The most important difference is that the Salvadorean plan did not have as its ultimate goal the promotion of cultural enlightenment or even the 'three Rs'; instead, it was conceived as part of a policy to use the mass media to accelerate economic development and prevent communism.

The ideas behind the link between the mass media and economic development had their origin in Second World War communications policies. Schramm, the chief investigator of the Stanford follow-up research in El Salvador, was perhaps the most influential voice in advocating the use of educational television in 'developing' countries for the consumption of what Arturo Escobar has called the 'development community' ${ }^{27}$ Schramm was so identified with the promotion of educational television in poor countries that the different stages of his career constitute a good road map for the origins of the ideas of using mass communications to promote development and prevent communism.

\section{Wilbur Schramm and the Use of the Mass Media to Promote Development and Prevent Communism}

Schramm's interest in communications as a social science stems from his participation in a network of intellectuals that were involved with the

25 The main document summarising the consensus reached by various organisations in the United States was the Carnegie Report: see 'Text of Summary and Recommendations in Report by the Carnegie Commission', New York. Times, 26 Jan. 1967; see also 'Tax on New TV Sets Urged to Help Educational Video', New York Times, 26 Jan. I 967.

${ }^{26}$ The US experiments that more closely resembled the Salvadorean project, such as the one in Washington County, Maryland, were all local efforts.

${ }^{27}$ Arturo Escobar, Encountering Development: The Making and Unmaking of the Third World (Princeton, 1995). 
psychological warfare teams established during the Second World War. ${ }^{28}$ The informal beginnings of this group can be traced to a seminar sponsored in 1939 by the Rockefeller Foundation that provided the guidelines for the use of mass communications in the war situation. ${ }^{29}$ The premise of the seminar, that government authorities and the ruling elite 'should automatically manipulate mass sentiment in order to preserve democracy from threats posed by authoritarian societies', was destined to have a lasting impact on the use of mass communications in poor countries. ${ }^{30}$

Although Schramm did not participate in the Rockefeller Foundation seminar, he became part of the emerging network of social scientists shortly afterwards, when he started working for the Office of Facts and Figures, soon to be renamed the Office of War Information (OWI), in January I $942 .{ }^{31}$ At the OWI Schramm collaborated with social and behavioural scientists who, among other things, surveyed public attitudes, crafted propaganda messages and monitored broadcasts. His wartime experiences were excellent training for the Cold War. During the Korean War the Air Force sent him, along with John Riley and Frederick Williams, to survey the situation in Seoul. Their report was later published in a widely circulated book, The Reds Take a City. ${ }^{32}$ Establishing continuity between the OWI days and his new work, Schramm described his Korean activities as being carried out as part of a 'psychological warfare team'. 33

To Schramm, psychological warfare was "nothing that a citizen of a democracy need to feel ashamed of doing, and it is conceived of as a fourth arm for attaining national objectives; the others are diplomatic, economic, and military'. In I 960 he advocated giving a high priority to 'active, militant, political communication'. ${ }^{34}$ In other words, during the I960s, at the same time as his work was being redirected from explicit psychological warfare to the field of international communications, Schramm kept his Cold War perspective.

Schramm described mass communications as a way of transmitting societal values. In I957, he wrote:

Mass communication helps us transmit the culture of our society to new members of society. We have always had teaching at mother's knee, and imitation of the

Christopher Simpson provides a fascinating account of the origins of this network in Science of Coercion: Communication Research and Psychological Warfare, 1945-1960 (New York, I 994).

29 Ibid., p. 22.

30 Ibid., p. 23.

31 Wilbur Schramm, The Beginnings of Communication Study in America: A Personal Memoir (Thousand Oaks, CA, i 997), p. I 33.

32 John W. Riley, Jr. and Wilbur Schramm, The Reds Take a City (New Brunswick NJ, I95 I).

33 John W. Riley Jr., Wilbur Schramm and Frederick W. Williams, 'Flight from Communism: A Report on Korean Refugees', Public Opinion Quarterly, vol. I 5, no. 2 (I95 I), p. 274.

34 Wilbur Schramm, review of Murray Dyer, The Weapon on the Wall: Rethinking Psychological Warfare, in Annals of the American Academy of Political and Social Science, no. 33 I (I 960), p. I 5. 
father - and still have. For thousands of years we have had schools of some sort or other. But mass communication enters into this assignment by supplying textbooks, teaching films and programs, and a constant picturing of the roles and accepted mores of our society. ${ }^{35}$

There was no great leap from this paternalistic metaphor to the use of communications to modernise 'traditional societies', a theme that Schramm developed in Mass Media and National Development, a much-quoted work. ${ }^{36}$ In this book Schramm put communications theory in the framework of modernisation theory, an approach that helped to shape US foreign policy and development policies in the Kennedy era. ${ }^{37}$

Modernisation theory incorporated an interpretation of the economic history of the industrialised nations that provided the foundations for a social science-based strategy against communist expansion. Walt Rostow's book, The Stages of Economic Growth, was one of the most influential explications of the theory. He subtitled his book 'A Non-Communist Manifesto', in order to present his work as an alternative to Karl Marx. Rostow constructed a narrative of the history of industrialised countries following a linear path with common benchmarks. Western Europe, North America and Japan had similarities not only in their economic evolution but also in how their societies changed. They started as 'Traditional Societies' and moved in well-defined stages to the 'Age of Mass Consumption'.

Traditional societies were economically stagnant; they had a ceiling in productivity. Their main economic activity was agriculture. They had a hierarchical political structure with very little mobility. Traditional peoples inhabited a pre-Newtonian world 'unmoved by man's new capability for regularly manipulating his environment to his economic advantage'. 38 More sociological formulations of modernisation theory, such as Daniel Lerner's, emphasised the institutions and values of people in traditional societies. They had authoritarian institutions and valued loyalty, obedience and inertia. Individuals lacked curiosity and initiative; they rarely ventured out of their small environment. For sustained economic growth to occur society had to be reoriented towards wealth maximisation, which required 'nothing else

${ }^{35}$ Cited in Wilbur Schramm, The Beginnings of Communication Study in America, p. I 47.

${ }^{36}$ Wilbur Schramm, Mass Media and National Development: The Role of Information in Developing Countries (Stanford, 1964).

${ }^{37}$ For excellent discussions of modernisation theory, see Michael E. Latham, Modernisation As Ideology: American Social Science and 'Nation-Building' in the Kennedy Era (Chapel Hill NC, 200o) and Nils Gilman, Mandarins of the Future: Modernisation Theory in Cold War America (Baltimore, 2003).

38 Walt W. Rostow, The Stages of Economic Growth: A Non-Communist Manifesto (New York, 1960), p. 5 . 
than the ultimate reshaping and resharing of all social values'. ${ }^{39}$ Lerner understood modernisation as a 'process of social change in which development is the economic component'. 40

In Rostow's view traditional societies moved to a second developmental stage, a transitional period where the 'preconditions for take-off' began to appear, often as a result of external intrusion by a more advanced society. This intrusion challenged traditional society and set in motion ideas and social values that began to advance society towards modernity. At the end of this transitional period the traditional societies encountered 'the great watershed in the life of modern societies', the 'take-off'. ${ }^{41}$ In this all-important stage, 'the forces making for economic progress, which yielded limited bursts and enclaves of modern activity, expand and come to dominate society'. Lerner specified the value changes associated with self-sustained growth: in a modern society individuals aspired to better themselves, to move up and around; they engaged in teamwork and participated in their polities. In a fourth stage, a prolonged period of self-sustained growth where modern technology spread to all economic activities (the 'Drive to Maturity') culminated in the 'Age of Mass Consumption'.

Much depended on the second stage, that of the "preconditions to takeoff', when the struggle between traditional and modern forces opened the door for the protagonism of competing forces of modernity, including communism. To Rostow, communism was 'a disease of the transition'. ${ }^{2}$ During this stage 'the seizure of power by Communist conspiracy is easiest; and it is in such a setting that a centralized dictatorship may supply an essential technical precondition for take-off and a sustained drive to maturity'. ${ }^{43}$ Ithiel de Sola Pool, who wrote a book with Schramm and was one of the proponents of modernisation theory, put the urgency of modernisation in similar Cold War terms: 'To the extent that a society is backward its potential contribution to support of America is small and its susceptibility to Communism large'. ${ }^{44}$ This line of thinking, developed in the I950s, became particularly compelling after the victory of the Cuban Revolution in I959. 'Those who make peaceful revolution impossible', said John F. Kennedy, alluding to the changes necessary to obliterate traditional forces, 'will make violent revolution inevitable', meaning a communistinspired upheaval. ${ }^{45}$

Daniel Lerner, 'Modernisation', in David L. Sills (ed.), International Encyclopedia of the Social Sciences (New York, i 968), vol. io, p. 387.

40 Ibid. $\quad{ }^{41}$ Rostow, The Stages of Economic Growth, p. $7 . \quad 42$ Ibid., p. I62.

${ }^{43}$ Ibid., p. I63. $\quad{ }^{44}$ Cited in Gilman, Mandarins of the Future, p. I90.

45 John F. Kennedy, 'Address on the First Anniversary of the Alliance for Progress', I 3 March 1962, in Woolley and Peters (eds.), The American Presidency Project, available at www.presidency.ucsb.edu/ws/index.php?pid $=9$ r 00. 
Traditional societies did not have to reinvent the wheel; they had the example of the path previously followed by more developed societies. The latter were 'the picture of their own future' - but to have a ticket to the future, people in traditional societies had to experience a profound transformation in their values. The mechanisms to usher traditional societies into modernity varied somewhat depending on the author, but they complemented each other. If Rostow stressed the importance of exogenous stimuli and an enlightened elite, for Lerner the mechanism of transformation was 'empathy', which he defined as 'the power to imagine oneself in a better situation' ${ }^{46}$ Fortunately, it was possible for the enlightened elite to instil empathy on the traditional population. The mass media of print, film and radio were the tool to achieve this goal. ${ }^{47}$ 'A basic function of the information campaigns in economic development', said W. Phillips Davison, was 'not only to teach new techniques but to activate and reinforce desires for change - to prepare the ground for the adoption of improved techniques and to focus attention on the desirability of new ways of behaving. ${ }^{48}$

Wilbur Schramm was one of the pioneers in explaining how the mass media could be used to inculcate empathy and to 'prepare the ground for the adoption of improved techniques'. His approach turned him into the foremost promoter of educational television in poor countries. Schramm cited Max Millikan and Donald Blackmer, who had stated that 'the paramount requirement of change in any society is that the people themselves must change'. To this comment Schramm added that 'this is the point where modern communication becomes so important to economic development ${ }^{49}{ }^{49}$ For Schramm, mass communication was the most effective instrument to turn traditional social structures into modern ones and, as Rostow and Pool had indicated, prevent communism. The mass media would increase the flow of information from industrialised countries and create a climate of change by raising people's aspirations (creating 'empathy', in Lerner's formulation). Schramm wrote:

In the service of national development, the mass media are agents of social change. The specific kind of social change they are expected to help accomplish is the transition to new customs and practices and, in some cases, to different social relationships. Behind such changes in behavior must necessarily lie substantial changes in attitudes, beliefs, skills, and social norms. ${ }^{50}$

Schramm believed that the way to achieve these changes was through the educational system. 'Public education is both a leading channel of

\footnotetext{
46 Lerner, 'Modernisation', p. 391. $\quad{ }^{47}$ Ibid.

48 W. Phillips Davison, International Political Communication (New York, 1965), p. I 5 I.

49 Schramm, Mass Media and National Development, p. 26; Max F. Millikan and Donald L. M. Blackmer (eds.), The Emerging Nations: Their Growth and United States Policy (Boston, I 96 I).

50 Schramm, Mass Media and National Development, p. I 4.
} 
information to the people and a chief support of the mass media', he wrote. ${ }^{\mathbf{5 1}}$ Such an argument about the link between education and mass media converged in the policy of instructional television:

Where teachers and schools are scarce they [the mass media] have proved to be of great help in adult education and literacy training ... These facts are important because, as we know, teachers and schools are scarce, and many of the available teachers are trained for yesterday's rather than today's teaching job. Technical skills are in short supply. ${ }^{\mathbf{5 2}}$

Schramm had profound faith in the effectiveness of educational television and became its main champion. He thought that television technology was an effective way to overcome the challenges encountered in poor countries:

In Chicago, the entire curriculum of a junior college is offered by television and studied quite successfully by hundreds of students who have no other contact with the college except at examination time or when they send in written assignments or ask questions. It may well be that in the atmosphere of need in a developing country, the media can carry a much larger share of the teaching load than they have been asked to carry in economically better developed countries.

...

To a country where highly trained teachers are scarce they [radio and television] offer the opportunity to share its best teachers widely. Where few teachers are trained to teach certain subjects, these media offer the hope that those subjects can be taught even before qualified teachers become available. ${ }^{\mathbf{3}}$

Schramm's work on El Salvador, and on educational television in general, was a direct outgrowth of the ideas expressed in Mass Media and National Development. The research project that he directed in El Salvador included measures of 'changes in attitudes, beliefs and social norms', and stressed the scarcity of qualified teachers. A document produced by Schramm's research centre in 1976 stated that TVE in El Salvador 'will provide young people with the skills and attitudes necessary to work in an industrial society'. ${ }^{\mathbf{5}}$ Echoing his work during the Second World War, Schramm's conception of mass communications was based on the premise that there was an enlightened elite that knew what was beneficial for the population at large and could use the mass media to advance its project.

The Salvadorean 'pilot project' was the result of his success not only in casting his ideas within the dominant paradigm of modernisation theory, but also in placing them on the agenda of the newly constituted international development community. His book, Mass Media and National Development, was crucial in this achievement since it helped to shape the communication policies of the United Nations Educational, Scientific and Cultural

51 Ibid., p. I Io. $\quad 52$ Ibid., p. I40. $\quad{ }^{53}$ Ibid., p. I44, I64.

${ }^{54}$ Cited in Jorge Ricardo Werthein, 'A Comparative Analysis of Educational Television in El Salvador and Cuba', PhD diss., Stanford University, I977, p. 237. 
Organization (UNESCO) in the I960s and early i 970 . In 1958 the United Nations General Assembly called for a " "program of concrete action" to build up press, radio broadcasting, film, and television facilities in countries in the process of economic and social development' ${ }^{\mathbf{5}}$ UN staff organised meetings on mass communications for Asia (Bangkok, I 960), Latin America (Santiago de Chile, I961) and Africa (Paris, I962) to develop policies in response to the General Assembly's mandate. ${ }^{\mathbf{5 6}}$ UNESCO took a keen interest in the issue and hired Schramm, already an established authority in the United States in the field of communications, to synthesise the discussions of the meetings and lay out potential policies. ${ }^{57}$ The product of his labours was Mass Media and National Development: The Role of Information in Developing Countries. The book was presented as a distillation of the discussions carried out in three different continents. ${ }^{58}$ In fact, the kernel of the main arguments in the book had been advanced in a document that he submitted to UNESCO prior to the meetings. The reports of the discussions that took place in Bangkok, Santiago and Paris touched only superficially on the ideas in Mass Media and National Development. ${ }^{\mathbf{5 9}}$ It is also worth noting that in this book Schramm did not mention the connection between economic development and the prevention of communism, as Pool and Rostow had done so explicitly. After all, the book was sponsored by an agency of the United Nations, which would have made such kinds of statement impolitic.

Wilbur Schramm was also a key participant in one of UNESCO's most important initiatives to promote instructional television, the three-volume New Educational Media in Action: Case Studies for Planners, published by UNESCO's International Institute for Educational Planning in 1967. The three volumes were accompanied by a Memo to Educational Planners that analysed the case studies and articulated their implications for education policies; its main author was Wilbur Schramm. Once again, his work had the aura of legitimacy by being presented as a synthesis of a major international effort. ${ }^{60}$ The volumes described experiences with educational mass media in areas as diverse as American Samoa, Hagerstown (Maryland), Japan,

55 Schramm, Mass Media and National Development, p. vii.

56 Ibid.

57 Schramm was later described by the UNESCO Courier as someone who had 'been closely associated with UNESCO for a number of years as a consultant, researcher, writer and editor and as an adviser to governments on UNESCO's behalf'. UNESCO Courier, vol. I 8 , no. 2 (1964), p. 26.

${ }^{58}$ Schramm, Mass Media and National Development.

59 See Wilbur Schramm, 'A Programme of Research for Mass Media Development', Paris, i6 Nov. I960 (mimeo document for the Meeting of Experts on Development of Information Media in Latin America, Santiago de Chile, I-I4 Feb. I96r), UNESCO Archive, UNESCO/MC/DEVLA/4 (the document is stamped for limited distribution); 'Report by the Director-General of UNESCO. Meeting on Development of Information Media in Latin America', I6 Feb. I96ı, UNESCO Archive, E/3437/Add. I, E/CN.4/814/Add. I.

60 Wilbur Schramm et al., The New Media: Memo to Educational Planners (Paris, 1967). The research for these volumes had been carried out with USAID funds. 
Australia, Niger, Colombia, Palestinian refugee camps, Italy, New Zealand and Honduras.

Through his work for UNESCO, Schramm helped shape the organisation's policies towards instructional television. His writings became obligatory works of reference and provided an outline for a narrative that would reappear constantly in reports by missions of international experts recommending educational television to poor countries. They repeated the main themes already present in the Samoan and Salvadorean reports.

But no matter how persuasive Schramm's ideas became or how enticing Lyndon Johnson's aid offers were, their role is not enough to explain the ambitious scale of the Salvadorean project and the ruthless enthusiasm of its implementation. When Lyndon Johnson approached President-elect Sánchez Hernández in Uruguay in 1967 , he was preaching to the converted. Salvadorean authorities had been exploring the possibility of using television technology in the school system prior to any US encouragement.

\section{The Introduction of TVE in El Salvador}

The idea of using television in Salvadorean classrooms was first mentioned to the Minister of Education some time in 196r by Walter Béneke, the charismatic Salvadorean ambassador to Japan. He admired NHK, the Japanese educational television system. After his initial conversation he made periodic visits to mid-level officers at the ministry to keep the idea alive. ${ }^{61}$ Official conversations between El Salvador and UNESCO concerning educational television began in 1963 during UNESCO's Thirteenth General Conference, when the Salvadorean minister of education, Professor Ernesto Revelo Borja, mentioned his country's interest in soliciting aid for a television-related project. ${ }^{62}$ The collaboration started modestly with the creation of two scholarships to study instructional television. ${ }^{63}$ Almost simultaneously, Béneke, who would later be promoted to become minister of education, obtained Japanese support to carry out a feasibility study. A few months later, the Salvadorean government appointed a commission to study the possibility of implementing a comprehensive instructional television project. The commission included representatives from the Consejo Nacional de Planificación (CONAPLAN), a new planning unit of the Salvadorean government created under the auspices of the Alliance for Progress, the

61 Interview with Gilberto Aguilar Avilés, 22 Aug. 2002. Aguilar Avilés was involved in the TVE project from the outset.

62 'Programa para el período 1963-1964, petición de El Salvador', AMS Aid to Member States Programme - Salvador, UNESCO Archive Reg. Xo7.2 I (728.4).

${ }^{63}$ UNESCO Director-General ad interim to Minister of Education, i 2 April I963, AMS Aid to Member States Programme - Salvador, UNESCO Archive Reg. Xo7.2 I (728.4). 
Ministry of Education, and a businessman involved in broadcasting. ${ }^{64}$ Ambassador Béneke joined the commission before the end of the year. The composition of the commission was characteristic of the governing style of the military regime that portrayed its decision-making process as purely technical and in full agreement with the private sector. The often-repeated phrase 'private sector' (empresa privada) was a euphemism that referred to the economic elite which had established the alliance with the army after 1932 that was at the core of the regime.

In 1964 the executive secretary of CONAPLAN delineated an ambitious programme in a letter to the World Bank:

Education, at the high school and university levels, is particularly important for accelerated economic growth. It is estimated that during the next five years it will be necessary to create at least 30,000 new jobs each year. Most of these jobs will be in the commercial, industrial and service sectors, and many of them will need training at the secondary or vocational school levels ...

Education by television could play an important role at all these levels. Particularly where school enrolments are small, the use of a monitor instead of a teacher could make it possible that high quality teaching would be available in places where it would not be otherwise. Supervision would be left in the hands of moderately trained teachers. The advantages of this system could be significant for secondary and vocational education in the rural areas of the country ${ }^{65}$

Other local antecedents facilitated acceptance of the project, with its modernisation theory premises. The theme of modernisation had been an integral part of El Salvador's governing strategies since the late I940s. The military officials in charge of the government had developed their own modernising discourse after the protracted demise of the dictatorship of General Maximiliano Hernández Martínez (193 I-44). Modernity was a highly selective matter for the military regimes. Modernisation projects were chosen on the basis of the needs of the economic elite; little attention was paid to the impact of new policies on the majority of the population, and policies were imposed from above without broad consultation. Modernity was more about hydroelectric dams to supply energy for new industries than about providing running water for the poor. It was identified with suspension bridges to bring cotton to the ports, but not with rural clinics. This understanding of modernity at the service of the economic elite was exemplified by the TVE Project. The main education reform decisions were destined to put education at the service of industrialisation.

64 Acuerdo Ejecutivo no. 6643, i 8 Octubre de 1963 , Diario Oficial (El Salvador), 3 I Oct. I 963 , p. $1026 \mathrm{I}$.

65 Guillermo Borja Nathan to Orvis Schmidt, Director of Operations, World Bank, 25 June i 964; Borja Nathan to Maheu, i Sept. 1964, Relations w. El Salvador - Official, UNESCO Archive Reg. Xo7.2I (728.4). 
A much debated point during the preliminary stages of the 1968 education reform was to determine the level at which educational television would be implemented. The authorities decided that too few students were progressing from primary school to middle school. A UNESCO consultant recalled the discussion as including the consideration that it was not a good idea to allow students to leave the educational system precisely at the point when they were ready to 'absorb knowledge and attitudes useful for economic development ${ }^{\prime 66}$ Minister Béneke referred to the middle school level as the 'foundation of the cultural $\operatorname{cog}$ and of economic development'. ${ }^{67}$

By 1969 the new television system began operating as an extended trial. It was used only for the seventh grade in 28 public and four private schools, covering the full curriculum (social studies, Spanish, mathematics, introduction to sciences, and English) for about a thousand students. ${ }^{68}$ In 1970 the new system was expanded to 219 classrooms of seventh-graders in public schools. It covered 54 per cent of all students in that grade. The 32 experimental classes that passed to eighth grade once again became the 'experimental group' to test TVE at a new level. ${ }^{69}$ Initially some private schools decided to experiment with the system, but most of them quickly returned to the traditional system. ${ }^{70}$ By I 972 , most students in the public middle schools where the television signal was available (about 60 per cent of the territory) received their classes from teleteachers. Plans to start experimenting with teleclasses in primary education by 1972 never came to fruition. Early on, international donor agencies determined that the 'pilot project' was a success and organised visits of observers from Ghana and the Ivory Coast to learn about the Salvadorean TVE experiences at first hand. ${ }^{71}$ In the perception of the UNESCO advisor, the advantage of educational television had to do with the ability to bring to each classroom specialised teachers 'with the same curriculum and the same quality control, and experiences that require high cost laboratories and aspects of modern scientific development'. The use of

66 Bruno E. M. Stiglitz, 'El Salvador: reforma educativa, Julio de 1967-Marzo de 1973', Paris, June 1973, UNESCO Archive, 2920/RMO.RD/ESM, p. 6.

67 'Superar educación media busca Béneke', Diario de Hoy, r6 Oct. I 968.

68 'Más de mil alumnos para TV Educativa', Diario de Hoy, 9 Feb. I969.

69 Schramm et al., 'Television and Educational Reform in El Salvador: Report on the Second Year of Research', AED Project Report Series, no. i 4 (Washington DC, I971), p. I4.

70

I 3 per cent of the 9,40I students in the seventh grade in the TVE system in 1970 were in private schools: Schramm et al., 'Television and Educational Reform in El Salvador, Report on the Second Year', p. I4.

71 Stephen Grant, 'An Administrative History of Out-of School Educational Television in the Ivory Coast' (AED, Washington DC, Dec. 1977); République de Côte d'Ivoire, Ministère de l'éducation nationale, Programme d'éducation télévisuelle 1968-1980, vol. 3, Rapport des missions d'évaluation de la télévision éducative au Niger, au Salvador et aux Samoa américaines (Abidjan); 'Misión africana llegará al país para conocer la TV educativa', Diario de Hoy, 23 Feb. I97I. 
television also permitted the optimal utilisation of teachers with a 'short and general training', who after a special preparation programme could teach with the help of television. ${ }^{72}$

The introduction of television at the middle-school level was coupled with a complete revamping of the programme of study. The innovations in the new curriculum, particularly in social studies, deserve some comment. The social studies curriculum for the seventh grade introduced numerous topics that encouraged students to become actors in the development of the country and to envision a better future. These topics were repeated and expanded upon in the eighth and ninth grades. Among the goals for the seventh grade, the curriculum included the need 'to encourage attitudes to interpret the continuity of history and to promote changes in the country'. ${ }^{73}$ The programme of study related the main subjects included in social studies to economic development. For example, another goal was 'to analyse how the geographical position of El Salvador in Central America contributes to its development'. Students were directed to organise groups to discuss 'the duty of citizens to contribute to the development of the country ${ }^{74}$ The authors of the curriculum wanted to make sure that pupils understood the need to apply new techniques to the task of development. The teacher's handbook suggested homework tasks such as investigating 'how science and technology have influenced the factors of production', analysing 'the changes experimented by the country thanks to the introduction of the hydroelectric and geothermic industries, ${ }^{75}$ or analysing the changes experienced by the country's economic activities thanks to 'the application of new methods and techniques'. ${ }^{76}$ The textbooks presented the government as guiding the country in the path to development. The curriculum included suggestions for ways in which the teacher could 'comment with learners on the need for the state to carry out public works' and students could 'investigate how branches of the state contribute to the commercial development of the country'.77 These heavy doses of Lernerian empathy were complemented with a contrast to the problems brought about by tradition; the social studies instructor was supposed to 'direct the analysis of the indigenous problem [el problema indigena] and suggest solutions'. ${ }^{78}$ The new curriculum was accompanied by new teachers' guides and textbooks that were perfectly coordinated with the television lessons. Teleclasses, textbooks, classroom activities, teacher remarks, and electronic, printed and verbal media were all synchronised to

72 Stiglitz, 'El Salvador: Reforma Educativa', p. 6.

${ }^{73}$ Ministerio de Educación, Documentos básicos de la Reforma Educativa 1o: programas de estudio del Séptimo Grado de Educación Básica (San Salvador, I971), p. 71.

75 Ibid., p. I 4 .

78 Ibid., p. 83. 
transmit to Salvadorean students the values that professors from MIT had decided would benefit 'traditional peoples'.

Records of the October i 968 planning meeting of the Stanford research project show that the correlation between the new curriculum and the tenets of modernisation theory was not coincidental. The meeting was attended by 22 individuals: eight from Wilbur Schramm's Institute for Communication Research, plus members of the Academy for Educational Development, the chairman of the Stanford Anthropology Department and one lone Salvadorean from CONAPLAN (Román Mayorga, a 26-year-old MIT-educated engineer). ${ }^{\mathbf{7 9}}$ The discussions on the design of the Salvadorean research project give a clear indication of what was expected of the education reform. Researchers were to collect information on learning, the cognitive impact of the new system, and changes in teaching styles. The members of the planning meeting were interested in the impact of the educational television project on industrial production and on cultural change. The questions they considered important to address in the research included:

Is there any industrial growth, any important addition to skills in the labor force, attributable to the new [educational television] technology? ... Is the new technology and the education on the air having any effects on values, customs, goals, or other aspects of the culture $?^{80}$

They also worried about the dangers of the rising expectations that could not be met: the 'revolution of rising expectations' was a preoccupation closely associated with modernisation theory. In the end, the research project could not explore all these areas because of a lack of funding, but the discussions are a good indication of what was expected of educational television. In general, the Stanford team expected the project to produce the results that Schramm had described in Mass Media and National Development.

The concept of the reform and the premises behind it ended up exacerbating long-standing conflicts in Salvadorean society. The matter, of course, was not whether hopes for a better future, a positive attitude to development, industrialisation, bridges, electricity, television or secondary education were beneficial or not; they clearly could bring good things. Many felt, however, that the model of development promoted by the new curriculum did not promise improvement for the economic situation of most Salvadoreans and that the reform was based on foreign ideas. ${ }^{81}$ Not only were the priorities of the government sharply skewed in favour of the desires

79 'Meeting of the Advisory Committee, Study of Instructional Television in El Salvador, October, I968', AED Project Report Series, no. I (Washington DC).

80 Ibid., pp. 3-7.

81 These views are succinctly expressed in 'Declaraciones del X Congreso de ANDES 2 I de Junio', 3 Dec. 1974, in Asociación Nacional de Educadores Salvadoreños 2 I de Junio (ANDES), Las luchas magisteriales en El Salvador (México DF, I980), p. 21. 
of the economically powerful, but the top-down execution of TVE and other development projects also showed little regard for how weak population groups could be affected.

In addition, the regime's overall idea of modernity had little space for political dissent. The governing military officials envisioned strict limits on opposition parties. The economic elites profoundly distrusted any notions of broader political participation. Collectively, both they and the military officials equated political participation aimed at expressing popular demands with communism. Despite the lack of any real communist threat in the r950s and I960s - in 1968 the CIA considered El Salvador's Communist Party to be 'small, illegal, intimidated, and generally ineffective' - the army and elites were driven by an aversion to communism that had its origins in an allegedly communist uprising in 1932 that their forefathers had defeated. ${ }^{82}$ The modernisation envisioned by the anti-communist military regimes between I 944 and I 979 was closer to the 'order and progress' ideas of the positivist rulers of the late nineteenth century (who had promoted the interests of coffee exporters by kicking Indian communities out of their lands) than to the group of anti-communist social scientists from MIT who promoted modernisation theory. Nevertheless, the rulers of El Salvador were keenly aware of developments in the international arena, especially those that allowed them to initiate public works projects and seek out millions of dollars in foreign aid. Savvy and always needing financial resources, leaders in El Salvador found it rewarding to couch their plans in the language favoured by the development community.

\section{The Salvadorean Context}

By 1967 the vision of modernity of the Salvadorean military regime was expressed by giving high priority to education while retaining the staunchly anti-communist and authoritarian characteristics of the political system. When Colonel Sánchez Hernández met President Lyndon Johnson in Uruguay, he had already made it clear that he was going to give education the highest priority in his administration. In an interview at his home the evening he was nominated as a presidential candidate, he had told a journalist that 'education has to go before anything else, because nothing can happen without education'. The other main issue he raised in the interview was

${ }^{82}$ The quotation is from Central Intelligence Agency, 'The President's Trip to Central America: Security Conditions, 3 July I 968', Special National Intelligence Estimate (SNIE) archive, 82/83-68, p. 4; on the 1932 uprising, see Héctor Lindo-Fuentes, Erik Ching and Rafael Lara-Martínez, Remembering a Massacre in El Salvador: The Insurrection of 1932, Roque Dalton, and the Politics of Historical Memory (Albuquerque, 2007), and Thomas P. Anderson, Matanza: El Salvador's Communist Revolt of 1932 (Lincoln NE, I971). 
anti-communism, insisting that "his position regarding the "red danger" would be as firm as possible ${ }^{83}$ He lived up to the dual promise of education reform and anti-communism contained in that initial interview. He saw education reform as a way to prevent communism, and when reactions to his reform turned negative, he quickly defined them as the 'red danger'.

The reform was carried out during a period of latent political crisis in Central America. President Johnson did not travel to El Salvador in 1968 to give away TV monitors; that is the type of chore normally assigned to vicepresidents. Presidents travel to places like El Salvador to advance agendas and resolve disputes. By 1968 the United States considered that social programmes were in need of 'presidential attention'. More importantly, the deteriorating relationship between El Salvador and Honduras had created frictions between the two countries that had the potential to derail the Central American Common Market, which leaders like Lyndon Johnson considered a key component of industrialisation and development in the region. ${ }^{84}$ President Johnson mediated in the dispute, but his visit only delayed the inevitable. War erupted between El Salvador and Honduras in 1969, causing the demise of the Central American Common Market and forcing thousands of landless Salvadorean peasants who had lived in Honduras as immigrants to flow back into El Salvador, which in turn raised political tensions inside the country.

After the war, the Salvadorean government, never a model of democracy, became even more authoritarian, and thanks to US military aid it had the resources to expand its coercive capacities. ${ }^{85}$ President Johnson, who was an adroit politician after all, was perfectly aware of the problem. After having dinner with Sánchez Hernández in Uruguay in 1967 he had commented that 'it was strange that those countries which we try to ignore because they are dictatorships seem to be our closest friends and our most trustworthy friends and would be the last to become Communist ${ }^{86}$ He referred unambiguously to Brazil, Paraguay, Nicaragua and El Salvador. At the same time the State Department was seriously preoccupied with the example provided by the

83 'Educación: principal objetivo de Sánchez H.', El Diario de Hoy, 25 Oct. 1966.

${ }^{84}$ For a detailed discussion of Johnson's trip, see Thomas M. Leonard, 'Meeting in San Salvador: President Lyndon B. Johnson and the 1968 Central American Summit Conference', Journal of Third World Studies, vol. 23, no. 2 (2006), pp. I I 9-46. For a discussion of the conflict between Honduras and El Salvador, see William Durham, Scarcity and Survival in Central America: Ecological Origins of the Soccer War (Stanford, I979), and Thomas P. Anderson, The War of the Dispossessed: Honduras and El Salvador, 1969 (Lincoln NE, I981).

85 See Robert H. Holden, 'Securing Central America against Communism: The United States and the Modernisation of Surveillance in the Cold War', Journal of Inter-American Studies and World Affairs, vol. 4I, no. I (I 999), pp. I-30.

${ }^{86}$ Lyndon B. Johnson, White House Diary, i 2 April I967, Lyndon B. Johnson Library and Museum, Austin, p. I I, available at www.lbjlib.utexas.edu/johnson/archives.hom/diary/ i $967 / 6704$ I 2-I I.asp. 
Cuban Revolution. US authorities understood the education reform in El Salvador in this context. They openly discussed the counterinsurgency aspect of the TVE project. 'There was a prevalent fear in the US State Department that Cuba may have set an example of revolution in Latin America and that American interests were in jeopardy there [in El Salvador]', stated a document submitted to the US Senate in I977. The document established a direct connection to the TVE project: 'To a considerable extent the ETV [educational television] project can be seen as an attempt to resolve these problems by establishing new linkages between various interest groups and reinforcing previously weak linkages' ${ }^{87}$

Behind a façade of openness, Salvadorean authorities set narrow limits on political participation. Opposition parties were allowed to organise but not to come into power; elections were rigged; customs officials decided which books could be allowed to enter the country and which qualified as subversive literature; labour organisation was strictly prohibited in the countryside, and only mildly tolerated in urban areas. ${ }^{88}$ The government kept extremists in check 'by repressive measures, including political assassinations', according to a 968 CIA report. ${ }^{89}$ In turn, many in the opposition, even those with no interest in communism, were inspired and energised by some of the reforms introduced in Cuba, and disenchanted with US policies in Cuba, Vietnam and the Dominican Republic.

It was within this context of the hardening of authoritarianism and growing anti-US sentiment that the Salvadorean government implemented its educational reform. The combination of a highly visible US presence, the powerful symbol of modernity in the form of television monitors, and the government's indifference to teachers' concerns assured intense conflict as the reform progressed.

Many teachers were not predisposed to opposing the reform or rejecting educational television. The problems in El Salvador's public education system were manifold, and the simple fact of implementing a reform at least carried with it the promise of positive change. Statistics gathered by the Stanford research team suggest that at the beginning teachers were receptive to educational television and various aspects of the reform. Their disenchantment was gradual.

${ }^{87}$ John H. Clippinger, 'Who Gains by Communications Development? Studies of Information Technologies in Developing Countries', Harvard University, Program on Information Technologies and Public Policy, Working Paper 76-I, p. I 28; Senate Committee on Foreign Relations, Subcommittee on International Operations, 'International Communications and Information: Hearings before Subcommittee on International Operations of the Committee on Foreign Relations', US Senate, 95th Congress, first session, 8, 9 and 1o June 1977 (Washington DC, 1977).

${ }^{88}$ Editorial, ECA: Estudios Centroamericanos, no. 26 (July I 97 I).

${ }^{89}$ Central Intelligence Agency, 'The President's Trip to Central America', p. 3. 
Yet some key features of the new system were bound to make teachers unhappy. The new way of looking at education as an instrument for development made it difficult for the authorities to realise that they were planting the seeds of alienation. Framing educational policy as a 'development project' changed the actors that participated in its implementation. In $1964 \mathrm{El}$ Salvador's Ministry of Education had no knowledge of CONAPLAN's initial request for World Bank support for TVE. When the UNESCO representative in El Salvador visited the education minister to inquire about the details of the project, the minister had no idea what he was referring to. ${ }^{90}$ This lack of communication between key government actors reveals the extent to which placing education within the framework of development policy affected the politics of knowledge among Salvadorean decision makers. In I 967, the Sánchez Hernández administration tried to create an autonomous institution to usher in the educational television project. The institution never became a reality, but the idea is helpful for understanding the vision behind the entire scheme. The Instituto Salvadoreño de Educación por Television, as it was called, would be the responsibility of a seven-member board, which would include two members appointed by business organisations, one by CONAPLAN, one by the president, and two by the Ministry of Education. ${ }^{91}$ The composition of the board gives a sense of the extent to which education policy was being taken away from the traditional actors as it was redefined as development policy. Businesspeople came to play a prominent role in designing the educational reform, signifying the rise of a new actor in the coalition of education policymaking. As the reform advanced, representatives of the industrial sector even participated in curriculum design. ${ }^{92}$ Veteran educators who believed in the importance of education but did not speak the language of the development community saw their power and influence decline rapidly. They were often individuals with long-lasting relationships with teachers, and in many cases they had been teachers themselves. The diminishing presence of these officials meant that there were few people making decisions who were capable of seeing and understanding the concerns of educators experiencing a profound transformation in the daily activities of their schools.

Roberto Posso E., Regional Chief ad interim of UNESCO's mission in Central America, to Juan Díaz Lewis, UNESCO Latin America Division Chief, 7 Sept. 1964, UNESCO Archive Reg. Xo7.21(728.4), TA 63/64 El Salvador - TA/CP 1963-64.

91 Comisión Nacional de Educación por TV, 'La televisión educativa en El Salvador', El Diario de Hoy, I 2 Sept. 1967.

92 The commission that revised the curriculum had nine members including representatives from UNESCO, CONAPLAN, the industrial association, the public university and the Ministry of Education. Manuel Luis Escamilla, Reformas educativas: historia contemporánea de la educación formal en El Salvador (San Salvador, I981), p. I 24. 
In a system where only 20 per cent of teachers possessed training appropriate for the class level in which they were placed, the challenges of the new method proved to be particularly difficult. The classroom instructor found the experience of teaching the new curriculum in tandem with the teleteacher to be a demoralising experience that exposed his or her personal limitations in front of the students. 'Students felt motivated seeing the well dressed teleteacher, someone with resources', remembered a former educator in an interview. 'A village teacher, with her looks, could not be equally motivating ... The rural teacher was affected in her self-esteem ${ }^{93}$ Unless they were charismatic, self-assured, well dressed and well trained, rural teachers were always on the losing side. In a social studies class observed in I975, the teacher had an authoritarian style that the students contrasted unfavourably with the charming teleteacher. Educators felt that any failure in the new system would be attributed to them, as television was the most modern method. The teleclass was expected to be a model of good education, 'but when it failed, the failure was attributed to the classroom instructor', said a former teacher and union activist. ${ }^{94}$ Interviews with former students confirm that the teachers' fear that television was undermining their standing in front of students was justified. One of them remembered how the 'new maths' teleclasses raised doubts that could not be solved locally; from the point of view of students the teleteacher 'was never wrong', so any unanswered questions were the fault of the local instructor. ${ }^{95}$ The son of a couple of teachers talked about the impact on his parents: 'The reform questioned who [they] were'. A union activist made a harsh assessment: 'The TV monitor was the replacement for the instructor; it said to her: "you know nothing", 96

Seemingly unaware of the educators' feelings, one of the Stanford reports stated approvingly: 'The classroom teacher's word is no longer the only word ${ }^{97}$ The teleteacher was promoted by the advocates of the system as a model to imitate, 'a model of good teaching techniques that can be emulated by the classroom teacher'. The Stanford reports did not see the interaction as a threat to the self-esteem of the local instructor but rather as an incentive to improve: 'In some instances, the classroom teacher develops a feeling of competition with the teleteacher, and he works very hard to show his students he is as competent and creative as the teleteacher. ${ }^{, 98}$ In the power

93 Interview with Susana Contreras de Santamaría, i 8 June 2005. All the interviews cited here were undertaken in San Salvador.

94 Interview with Julio César Portillo, 28 June 2005.

95 Interview with Carlos Gregorio López, 9 July 2007.

96 Interview with Rosa Margarita López de García, 28 June 2005.

97 Hornik et al., 'Television and Educational Reform in El Salvador - Summary Report', p. 156.

98 Ibid., p. I 58. 
conflict between live educators and the image on television, however, the latter invariably won, and the researchers could not see it. The attitude of resistance among teachers can be inferred from a class observation carried out in 1976 by a doctoral student:

Since there was only one [television] set, the fifth-grade students who had been to the previous class were moving their supplies and chairs into the other classroom, while those who were going to have the teleclass entered the room with the set. The teacher came and turned on the set five minutes after the class had begun; meanwhile, the change of groups and furniture was not yet finished, so students continued to come and go with books and benches; two students swept the floor of the classroom while the teacher, seated at her desk totally removed from what was going on, wrote something in a notebook; and in the front of the room the television, uncovered and plugged in on its pedestal, transmitted the day's teleclass. ${ }^{99}$

Early in the process the Stanford researchers recognised the problems raised by the classroom teachers' lack of training. The Ministry of Education took two countermeasures to rectify the problem: closer supervision and intensive training. The supervision infantilised classroom teachers and the training had the opposite effect: it gave them more skills and made them eager to try out their new knowledge on students. The problem was that the newly trained instructors went back to a frustrating system in which they played a supporting role to the teleteacher. Furthermore, the retraining involved a complete restructuring of the teacher training system, which was done in the authoritarian manner typical to the military regime that was overseeing it. The Ministry of Education simply ordered the closing of all private and public normal schools and created a new centralised institution to retrain teachers and educate new ones. In its heyday the Escuela Normal Alberto Masferrer, as the new institution was called, had up to 900 students enrolled.

The next step was to get more students into school to take advantage of educational television. The Ministry of Education eliminated the customary tuition payments at the seventh-, eighth- and ninth-grade levels. The initiative had the expected results - enrolment increased by 35 per cent - but teachers paid a heavy cost. Space was limited, and schools had to go to a split morning/afternoon schedule, which meant that teachers taught their daily curriculum twice to two different sets of students. In short, they had more work and more students with only a nominal increase in pay. ${ }^{100}$ The fact that budget constraints were going to be a problem and that teachers had to absorb the costs in terms of greater workloads was not unexpected. Three of

99 Werthein, 'A Comparative Analysis', p. 272.

100 Hornik et al., 'Television and Educational reform in El Salvador: Report on the Third Year of Research', AED Project Report Series, no. I7 (Washington DC, 1972), p. i. 
Schramm's doctoral students who participated in the research expected as much in an article they wrote for UNESCO's journal:

Although ITV [TVE] was unquestionably an expensive innovation for El Salvador, the Ministry of Education managed to offset some of its cost by increasing both classroom teachers' hours and class size. Given the projected rise in enrolments, the per student costs of instruction under the reform with ITV will eventually be less than if the reform had been introduced with traditional class size and teacher loads. ${ }^{101}$

The promise that TVE was going to save costs was later described as a 'catch 22 ' situation:

When student enrolment increases without parallel increases in the number of teachers and facilities, the stresses on the teachers reach a breaking point; teachers demand pay increases and reduced work loads. The Salvadoran government resisted the teachers' demands so as to keep educational costs down, as reduced cost was one of the rationales behind ETV's [TVE's] use. However, in order to reduce the per student cost of ETV it was necessary to greatly increase the number of students. It would appear, then, that ETV may have put the Ministry of Education in a 'catch 22 ' type situation: in order to reduce per student costs, student enrolment had to be increased, but increased enrolment meant additional teachers and facilities, and hence, increased costs. ${ }^{102}$

In sum, even though teachers did not start out inherently opposed to the reform or to educational television, their experiences were such that their resentment increased steadily. Within a couple of years they saw their daily routines radically altered, were presented with threats to their self-esteem, and had to do more work for little additional pay.

The teachers' union, the Asociación Nacional de Educadores Salvadoreños $2 I$ de Junio (ANDES), which represented the largest number of civil servants in the country ( 17,292 teachers in 1970), emerged as a constant defender of the teaching profession. ${ }^{103}$ Teachers began organising in 1963 and the union was legally recognised in $1967 .{ }^{104}$ Traditionally the government had considered the teaching profession to be a reliable piece of its patronage machine, a dependable ally that could be manipulated for political purposes. The government saw educators as 'followers of the official position' almost by definition. ${ }^{\mathbf{1 0 5}}$ 'Teachers and soldiers', said the army's official publication in 1950, 'have come to understand and complement one another in improving the fatherland and assuring that its future is prosperous and

\footnotetext{
101 Mayo et al., 'Instructional Television in El Salvador's Educational Reform', pp. i $25-6$.

102 Clippinger, 'Who Gains by Communications Development?', p. I I 4.

103 US Agency for International Development, Statistics for the Analysis of the Education Sector: El Salvador (Washington DC, I973), p. 73.

104 Arnoldo Vaquerano, 'Breve reseña de los orígenes y desarrollo de la organización del magisterio salvadoreño', manuscript provided by Vaquerano to the author.

105 Interview with Julio César Portillo, 28 June 2005.
} 
glorious. ${ }^{\mathbf{1 0 6}}$ Many teachers, however, did not appreciate being taken for granted. ${ }^{107}$ One of the founders of the union bitterly recalled an episode during the administration of Oscar Osorio (1950-6). The government, he reminisced in an interview, "purchased a good number of new school desks for the schools, [and] on December I 4 of that year he [Osorio] made teachers participate in a parade on top of trucks, sitting on the desks with the flag of the PRUD [the official party]'.108

In late 1967 and early 1968 , the new union took advantage of the discussion of new legislation regarding benefits for public employees to press for better benefits for teachers. Some members of the union remember today that their motivation to participate was not limited to a struggle for benefits. 'To start with', explained one of them, 'we had to make the government show us respect. ${ }^{109}$ The government swiftly rejected their demands, however. This led to ANDES declaring its first massive work stoppage in I 968. It ended with some concessions to the teachers but without a long-term resolution to the conflict. The strike was not particularly successful in obtaining concessions, but it greatly enhanced the reputation of the new union among disaffected educators. 'Before 1968 I hadn't heard much of ANDES,' recalled a teacher in an interview, 'but after the strike, a teacher's world revolved around ANDES. ${ }^{110}$ In his work on popular mobilisation Paul Almeida characterises this strike as the largest in El Salvador up until that moment and as being a 'major force in creating political awareness not only for teachers, but for a whole generation of sympathetic social sectors'. ${ }^{111}$

The government's ongoing intransigence and the flurry of changes introduced by the education reform in subsequent years further promoted the teachers' desire to engage in collective action. In December i 970 ANDES convened a national congress to discuss the reform, and later it organised regional seminars with students and teachers. According to Mélida Anaya Montes, one of the union's founders, the first months of $197 \mathrm{I}$ 'were months of an intense evaluation of the curricula by the teachers'. ${ }^{112}$

Boletín del Ejército (1950), cited by Erik Ching, 'Local Politics Meets a National Modernisation Project: How Teachers Responded to the 1968 Educational Reform in El Salvador', paper presented at the 2007 Congress of the Latin American Studies Association, Montreal.

107 Víctor Valle, Siembra de vientos: El Salvador, 1960-69 (San Salvador, I 993), p. 96.

108 Interview with Arnoldo Vaquerano, i 8 July 2007. Vaquerano has been in the leadership of ANDES since its origins. He was a member of the Executive Committee of the union seven times, and has been its secretary-general.

109 Interview with Julio Gómez, 25 June 2005.

110 Ibid.

111 Paul Almeida, Waves of Protest: Popular Struggle in El Salvador, 1925-2005 (Minneapolis, 2008), p. 92. This is a widely accepted view: see also Mario Lungo, La lucha de las masas en El Salvador (San Salvador, 1987), p. 62.

112 Mélida Anaya Montes, La segunda gran batalla de ANDES (San Salvador, I972), p. 32. 
The relationship between the reform and the struggle of teachers was complex. The demand for greater respect had deep roots in decades of government manipulation, and the fight for better working conditions had been the starting point for activism. The reform added fuel to a fight that had already begun. Arnoldo Vaquerano, another founding member of ANDES, mentioned in an interview that teachers resented the fact that they had not been consulted on the design of innovations that had a profound impact on their profession. Even if educational television had directly affected only the relatively small number of teachers at the middle-school level, it was seen as a portent of things to come. Teachers saw their future endangered. 'One of the objectives that they had established', Vaquerano stated, 'was to stop the production of new instructors, that is, with a TV monitor in the classroom and a team of educators teaching classes from the headquarters of educational TV ... they needed no more than two or three teachers for several grades'. The reform also implied a sense of direction for the economic development of the country with which union leaders did not agree: 'The development of the country had to be based on that education reform; the mistake was in the way in which they tried to develop [the country] ${ }^{113}$ ANDES representatives also argued that although the education budget had increased considerably, most of the new funds were directed to pay for educational technology rather than teachers. ANDES launched its second major work strike in I 97 I. It too ended after a couple of months and some concessions to the teachers.

The I968 strike found impressive support among university students, parents, high school students and members of the Federacion Unitaria Sindical de El Salvador (FUSS), who together formed a movement to support the strike, the Frente de Acción Nacional Pro Derechos de los Educadores Salvadoreños (FANDES). By the time of the I97 I strike ANDES received even stronger support from an already growing opposition movement. Paul Almeida describes how the strike 'tapped into the organisational infrastructure support of Catholic labor unions, FUSS, FESTIAVTCES [Federación Sindical de Trabajadores de la Industria de Alimento, Vestido, Textil, Similares y Conexos de El Salvador], public sector unions, high school and public university student associations, the newly formed Jesuit university, oppositional political parties, and even the incipient peasant movement'. ${ }^{114}$ The strikes mobilised up to 50,000 people including teachers and their supporters. To put this figure in context, in 1970 the total labour force involved in manufacturing was around 108,000 workers. ${ }^{115}$ In the key decade between 1962 and 1972 , the period when most of the civil society infrastructure that played a major role in the

113 Interview with Arnoldo Vaquerano. The fear that television was going to displace teachers was common: see also Valle, Siembra de Vientos, p. 97.

114 Almeida, Waves of Protest, p. 93.

115 Agency for International Development, Statistics for the Analysis of the Education Sector, p. 46. 
mass mobilisations of the late I970s and early i980s was created, the teachers' strikes were pivotal moments. ANDES positioned itself 'in the vanguard of the class struggle', according to one observer. ${ }^{\mathbf{1 1 6}}$

The strikes also provided an occasion for the recently organised paramilitary organisation, the Nationalist Democratic Organisation (Organizacion Democratica Nacionalista, ORDEN), to flex its muscles, intimidating teachers and providing assistance to the police and the National Guard to keep union supporters in check at the local level. ${ }^{117}$ In i 968 the government killed two workers who supported the strike, and the university student organisation claimed that at least 500 people were detained. ${ }^{118}$ In the following months the Ministry of Education systematically fired, or transferred to distant towns, teachers who had been particularly active. This action created a great deal of resentment. ${ }^{119}$ After the I97 I strike ORDEN harassed schools where the teachers were organising, and the police attacked a student demonstration. One leader's home was subjected to an arson attempt, while others saw their homes attacked with stones and machine gun blasts. Finally, a member of the union was murdered on i 8 August. ${ }^{120}$ The physical attacks were accompanied by an intense newspaper campaign against the union. After i97 I leaders of the organisation became a frequent target of the security forces. ${ }^{121}$

The Stanford team's reports provide a snapshot of the scale of the I97 I strike. They reveal that only five of the 45 schools the team monitored operated as usual. Outside those schools, 'maybe is to $25 \%$ of the classes were carried out, but sometimes with interim teachers and few students' ${ }^{122}$ The recently installed television monitors provided the insult that added to the injury of the ministry's intransigence towards the teachers' demands. Televised classes continued as normal, creating the impression that the government truly believed that an electronic box with canned classes could replace teachers. ${ }^{\mathbf{1 2 3}}$

It seems obvious to attribute the origins of the teachers' activism to a steady accumulation of irritants : the instrumentalism of the official party, the conflict over benefits, the ruthless implementation of the educational reform, the abrupt closing of normal schools, the dramatic redefinition of work, the disproportionate expense on technology without a corresponding increase in

\footnotetext{
116 Lungo, La lucha de las masas, p. 62.

117 Interview with Julio Flores; see also Michael McClintock, The American Connection: State Terror and Popular Resistance in El Salvador (London, 1985), p. I63.

118 For a detailed discussion of the 1968 strike and the repression that followed, see Ching, 'Local Politics Meets a National Modernisation Project'.

119 Lungo, La lucha de las masas, p. 60.

120 Anaya Montes, La Segunda Gran Batalla de ANDES, pp. 47-6o, I04.

${ }^{121}$ For a table of acts of repression against union leaders, see Almeida, Waves of Protest, p. I 22.

${ }^{122}$ Hornik et al., 'Television and Educational Reform in El Salvador, Report on the Third Year', p. ıо.

123 Ibid., p. го.
} 
teachers' pay, the growth in class sizes, the increase in working hours, and the fear of being displaced by machines. The government, however, responded by accusing teachers of being communists and of trying to turn El Salvador into the next Cuba. ${ }^{124}$ Certainly, El Salvador's Communist Party and other leftist organisations had a presence in the teachers' union and took an interest in the teachers' cause. ${ }^{125}$ The leftist presence was numerically small, however, and nowhere near in proportion to the government's description. The vast majority of teachers in the union and of those who participated in the strikes were individuals of moderate politics who engaged in collective action in hopes of forcing the government to address what they saw as reasonable grievances. A study by the Jesuit university concluded that the conflict was a symptom of the 'deficient situation of the teaching profession', and that the 'income level of teachers is below their social cost of living'. The government's authoritarian response quickly polarised the situation to the point that many teachers did eventually join the militant Left in the later i970s. The strikes, and the government's reaction to them, promoted popular mobilisation of teachers and students, and helped the opposition movement to reach university and high school students, young people who grew up seeing the government as the enemy. They flocked to the militant opposition when the opportunity presented itself. ${ }^{126}$ ANDES became, according to James Dunkerley, 'an independent political force of considerable standing in the country'. ${ }^{127}$

\section{The Outcome}

Modernisation theory fell into disfavour. Conservatives criticised its mechanical social engineering; dependency theorists questioned the inexorable progression to development and argued that the wealth of the industrialised nations was only possible thanks to the exploitation of 'traditional societies'; anthropologists, in turn, moved away from 'development anthropology' and began to emphasise the impact of conquest, imperialism and economic exploitation in poor countries. ${ }^{128}$ By 1975 modernisation theory was almost irrelevant.

124 Government-sponsored newspaper publications made this point: see Diario de Hoy, 7 and 9 July I 97 I.

125 Cynthia McClintock states that Anaya Montes became a member of the Communist Party 'at some point during the ig6os'. Her source is a biographical sketch in a document issued by the Commission on US-Central American Relations published in 1982: see Cynthia McClintock, Revolutionary Movements in Latin America: El Salvador's FMLN and Peru's Shining Path (Washington, i 998), p. 257.

126 See, for example, Almeida, Waves of Protest, pp. 92-3; McClintock, The American Connection, p. I65; and James Dunkerley, The Long War: Dictatorship and Revolution in El Salvador (London, I982), p. 69.

127 Ibid., p. 99.

128 For an account of the demise of modernisation theory, see Gilman, Mandarins of the Future, Chapters 6 and 7; see also James Ferguson, 'Anthropology and its Evil 
In 1979 Wilbur Schramm revisited his path-breaking book, Mass Media and National Development. ${ }^{129}$ He began his comments by saying, 'I have just had the humbling experience of rereading a book I wrote 17 years ago', and went on to admit that he 'should've been more sceptical about the applicability of the Western model of development'. He conceded that after two decades there was very little success of which to be proud. Recognising that the failure was one of 'strategy rather than tactics', he acknowledged that the development of the West was a very specific historical accident and that there was no reason to believe that it could be reproduced step by step.

There is something moving about the image of an ageing intellectual sitting down to write an acknowledgment of the failure of his theories, but the demise of the Salvadorean offspring of modernisation theory was downright tragic. El Salvador's Ministry of Education slowly abandoned educational television in the late I970s and early I980s. The TV monitors fell into disrepair and guerrillas bombed the transmission towers. The taped lessons were destroyed during the civil war when the broadcasting station was taken over by the government's political communication officers. ${ }^{130}$ ANDES became part of the Revolutionary Coordinator of the Masses (Coordinadora Revolucionaria de las Masas, CRM), an umbrella group of organisations supporting the guerrillas. Death squads announced in 1975 that they would eliminate union leaders, and identified teachers as one of their main targets. ${ }^{131}$ Eventually most educators either directly or indirectly experienced repression or had friends or relatives victimised by the government. 'My sixth grade teacher was killed in 1969 for having participated in the 1968 strike ... Four in my graduating class were killed and we were 44', reminisced a former teacher. ${ }^{132}$ Minister Béneke was assassinated in 1980 by a guerrilla group. ${ }^{133}$ Mélida Anaya Montes was murdered in April 1983 , stabbed dozens of times by a rival guerrilla. ${ }^{134}$

Perhaps the most dramatic metaphor for the fate of the TVE-led educational reform was the closing of the teacher training school to turn it into a

Twin: "Development" in the Constitution of a Discipline', in Frederick Cooper and Randall Packard (eds.), International Development and the Social Sciences (Berkeley, 1997).

129 Wilbur Schramm, 'Mass Media and National Development - I979', typewritten document prepared for the International Commission for the Study of Communication Problems, UNESCO Archive.

130 Interview with Eduardo Suvillaga, 23 Nov. 2004.

131 'Political Violence Increases', Facts on File World News Digest, 29 Nov. 1975, p. 893; Dunkerley. The Long War, p. 69.

132 Interview with Susana Contreras de Santamaría, i 8 June 2005.

133 Interview with Eduardo Sancho, 20 July 2007. Sancho, a guerrilla commander during the Salvadorean Civil War, confirmed during this interview that Béneke was killed in a guerrilla operation. To my knowledge, this is the first time this has been acknowledged.

134 Christopher Dickey, 'Salvadoran Rebel Intrigue: Dispute Leads to Deaths of Two Guerrilla Leaders', Washington Post, 27 June 1983. 
garrison for the infamous, US-trained Atlacatl Battalion, a military unit responsible for some of the worst human rights violations during the civil war.

Was the promise of educational television ever realised? Seventh-, eighthand ninth-grade enrolments increased, but with disastrous results for teachers' morale. Test scores rose as well, but it was never possible to say without ambiguity that better scores were the result of television or of curricular changes and teacher training. Moreover, technical difficulties undermined the project. Coverage was limited to 60 per cent of the country, and poor maintenance meant that it was not uncommon to find that 'one out of two' television sets were out of service in a school. ${ }^{135}$ Without counting the capital expenses, the operating cost of educating each student increased at least I 3 per cent, making the cost-effectiveness of educational television an unrealised dream. ${ }^{136}$

It would be inaccurate to assert that the reason for El Salvador's adoption of a radical instructional television project was simply ruthless optimism, unbridled faith in modernisation theory, or the influence of international experts who had 'the moral, professional, and legal authority to name subjects and define strategies' ${ }^{137}$ The rapid and ambitious transformation of the Salvadorean educational system was possible because Salvadorean leaders had a strong desire to improve education, and to do so according to their distinct definition of modernisation. They certainly were heavily influenced by foreign experts, foreign governments and international aid organisations, but the top-down implementation of the project was a continuation of patterns of government established as far back as the nineteenth century. The Salvadorean elite had established a power structure unaccustomed to negotiation or to listening to mass opinion. Their virulent anti-communism was rooted more in socially constructed memories of the country's past than either historical evidence or the influence of outsiders. They routinely used the coercive powers of the state to suppress dissent without regard for legal or human rights constraints.

The financial support that provided the means for the Salvadorean state to act on a large scale was a rare instance of the Alliance for Progress behaving according to the ideas behind its inception. The clear application of modernisation theory sets the TVE experiment apart from the bulk of US aid projects of the same period. The numerous projects executed all over Latin America in the I960s and I970s defy a common description. Even if the original policy was inspired by works of modernisation theory like Millikan and Rostow's A Proposal: Key to an Effective Foreign Policy, Alliance funds were

135 Werthein, 'A Comparative Analysis', pp. 264, 270.

136 R. E. Speagle, Educational Reform and Instructional Television in El Salvador: Costs, Benefits and Payoffs (AED, Washington DC, I973), p. 9.

137 Escobar, Encountering Development, p. 4I. 
directed to initiatives on the ground that reflected a myriad of political and bureaucratic compromises. ${ }^{138}$ Scholars have pointed out that US foreign aid to Latin America quickly deviated from the lofty goals announced by President Kennedy and became a mishmash of ad-hoc initiatives driven more by immediate counterinsurgency goals than by the desire to bring about long-term social change. The results of the Alliance were definitely mixed and, as a whole, scholars regard its failure as being attributable to counterinsurgency obsessions, bureaucratic infighting, local manipulation, opposition in the host countries, and insufficient funds. ${ }^{139}$ One can find wellexecuted ideas among the various projects, even pioneering efforts like Paulo Freire's first literacy project in Brazil. ${ }^{140}$ Defenders of the Alliance also point out that the programme had successes that included the strengthening of infrastructure and the creation of planning bureaucracies, but the aspirations of the Alliance were never fulfilled. ${ }^{141}$ Ironically, the educational television initiative in El Salvador, a resounding failure, was a social programme that represented a late bloom of modernisation theory in one of its purest forms, free of deviations from the original concepts. It was a rare case of a wellfunded plan that sought to transform 'traditional society'. It was carried out as completely as could be expected, and was implemented with Olympian indifference to local resistance. As an effort to expand access to education it can be considered a 'plain vanilla' social programme, far away from the military aid or standard counterinsurgency projects that gave the Alliance a bad name.

The project was possible thanks to a convergence of interests and perspectives; it brought together international and local actors in a complex web of negotiation. International government officials, aid agencies and academics approached El Salvador from their distinct perspective of modernisation and aid. Governing officials were happy to receive the financial and intellectual resources put at their disposal, but always within the context of their own definition of progress and modernisation. Teachers at the grassroots level were initially open-minded but eventually turned against the project. The demise of TVE throws into relief the complex dynamics that

${ }^{138}$ Max F. Millikan and Walt W. Rostow, A Proposal: Key to an Effective Foreign Policy (New York, 1957).

${ }^{139}$ For insightful critiques of the Alliance, see Stephen G. Rabe, The Most Dangerous Area in the World: John F. Kennedy Confronts Communist Revolution in Latin America (Chapel Hill NC, I999); and Walter LaFeber, Inevitable Revolutions: The United States in Central America (New York, 1983$)$.

140 Jerome I. Levinson and Juan De Onís, The Alliance that Lost its Way: A Critical Report on the Alliance for Progress (Chicago, 1970), p. 288.

141 See L. Ronald Scheman (ed.), The Alliance for Progress: A Retrospective (New York, I988); some of the chapters in this volume are by members of John F. Kennedy's original Alliance team. 
arise when seemingly unquestionable ideas about modernisation and development are turned into concrete policies by interactions among real people at the international, national and local levels.

The Cold War and modernisation theory aspects of the project were an important element in its dismal results. The theory's emphasis on a modernising elite, and on the power of the state to bring about swift change, reinforced elements already present in the political culture of the local ruling class. TVE was inspired by an understanding of communications for development that had the Cold War in its DNA and used research tools to fine-tune a predetermined elite message rather than to listen to what people at the local level may have wanted. Education authorities with roots in the teaching profession were displaced by planners, development experts and individuals with links to the economic elite. Nothing in the experience of the new authorities helped them to understand the radical transformation suffered by the teachers' classroom experience. This blind spot had serious consequences in teacher-government relations as the education reform was implemented. The very theory being applied created other blind spots that exacerbated the problem. Teacher resistance to TVE was understood at best as temporary resistance to modernity and at worst as being communist-inspired. The followers of a theory that privileged the role of an assertive modernising elite were not equipped to perceive the negative consequences of the exceedingly assertive actions of the modernising elite.

The words spoken in 1968 by Lyndon Johnson at the Salvadorean teachers' school and quoted at the beginning of this article - 'If educational reform succeeds [in El Salvador], then all else that we are trying to do will succeed. If it does not succeed, and succeed swiftly, then no amount of good will or economic investment will be sufficient' - expressed both the sense of urgency and the attitude of self-confidence that doomed the project. ${ }^{142} \mathrm{~A}$ problem perceived as serious could be promptly solved by the unflinching implementation of the best social science-based solution. In the end, the application of modernisation theory and the millions of dollars that rewarded it reinforced the worst features of an authoritarian regime and helped to precipitate the outcome that it was designed to prevent. The TVE project, despite its apolitical, technical language and appeals to modernity, provided an excellent illustration of the 'state structures and practices' that, according to Jeff Goodwin, 'matter ... for the very formation of revolutionary movements'. ${ }^{143}$

\footnotetext{
${ }^{142}$ Johnson, 'Remarks at the Alberto Masferrer Normal School'.

143 Goodwin, No Other Way Out, p. 25.
} 


\section{Spanish and Portuguese abstracts}

Spanish abstract. Este artículo investiga la introducción de la televisión educativa en El Salvador a finales de los años 6o. Tal iniciativa fue un proyecto de la Alianza para el Progreso, bajo las preocupaciones de la Guerra Fría, la aplicación de la teoría de la modernización, la creciente influencia de una comunidad desarrollista basada en las ciencias sociales, y la particular obsesión con el comunismo de la élite salvadoreña. El enfoque de arriba-abajo utilizado por el régimen militar para introducir gran cantidad de cambios en el sistema educativo fue facilitado por los extensos recursos otorgados por agencias internacionales de ayuda y por el gobierno estadounidense. Sin embargo, las reformas alienaron a los profesores salvadoreños y alentaron las huelgas de maestros que aún se recuerdan como momentos fundamentales en los movimientos de masas urbanos de los años 70 y que precedieron a la guerra civil una década después.

Spanish keywords: El Salvador, Alianza para el Progreso, teoría de la modernización, UNESCO, televisión educativa, ayuda extranjera, Wilbur Schramm

Portuguese abstract. $\mathrm{O}$ artigo analisa a introdução da televisão educativa em El Salvador no final da década de I960, um projeto da Alianza para el Progreso, e considera as preocupações acerca da Guerra Fria, o emprego da teoria da modernização, a influência crescente de uma comunidade desenvolvimentista baseada nas ciências sociais, e a obsessão especial da elite salvadorenha com o comunismo. A abordagem impositiva do regime militar ao introduzir uma rajada de mudanças no sistema educacional facilitou-se pelos extensos recursos fornecidos por agências internacionais de assistência e pelo governo dos Estados Unidos. No entanto as reformas alienaram professores salvadorenhos, dando munição a greves, ainda lembradas como momentos críticos dos movimentos de massa urbanos da década de 1970 que antecederam a guerra civil da próxima década.

Portuguese keywords: El Salvador, Aliança para o Progresso, teoria da modernização, UNESCO, televisão educativa, assistência internacional, Wilbur Schramm 